\title{
Was Myriophyllum spicatum L. (Haloragaceae) recently introduced to South Africa from Eurasia?
}

\section{Authors: P.S.R. Weyl, R.A. Thum, M.L. Moody, R.M. Newman, and J.A. Coetzee}

This is a postprint of an article that originally appeared in Aquatic Botany on January 2016.

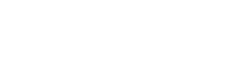

Weyl, P.S.R., R.A. Thum, M.L. Moody, R.M. Newman, and J.A. Coetzee. "Was Myriophyllum spicatum L. (Haloragaceae) recently introduced to South Africa from Eurasia?." Aquatic Botany 128 (January 2016): 7-12. DOI: 10.1016/j.aquabot.2015.09.003.

Made available through Montana State University's $\underline{\text { ScholarWorks }}$ scholarworks. montana.edu 


\title{
Was Myriophyllum spicatum L. (Haloragaceae) recently introduced to South Africa from Eurasia?
}

\author{
P.S.R. Weyl ${ }^{\mathrm{a}, *}$, R.A. Thum ${ }^{\mathrm{b}}$, M.L. Moody ${ }^{\mathrm{c}}$, R.M. Newman ${ }^{\mathrm{d}}$, J.A. Coetzee ${ }^{\mathrm{a}}$ \\ a Department of Zoology and Entomology, Rhodes University, Grahamstown 6140, South Africa \\ ${ }^{b}$ Department of Plant Sciences \& Plant Pathology, Montana State University, Bozeman, MT, USA \\ ${ }^{c}$ Department of Biological Sciences, University of Texas at El Paso, El Paso, TX, USA \\ ${ }^{\mathrm{d}}$ Department of Fisheries, Wildlife, and Conservation Biology, University of Minnesota, St. Paul, MN, USA \\ * Corresponding author. Fax: +27466228959 . \\ E-mail addresses: philipweyl@gmail.com, p.weyl@ru.ac.za (P.S.R. Weyl).
}

\begin{abstract}
There is debate over the native or exotic status of Myriophyllum spicatum L. (Haloragaceae) in South Africa, which has important implications for developing and implementing management strategies. The aim of this study was to determine if $M$. spicatum was recently introduced from Eurasia by reconstructing the genetic relationships between South African and Eurasian $M$. spicatum using both a nuclear riboso-mal (ITS1-5.8S-ITS2-26S) and a chloroplast intron (trnQrps16) sequence from 40 populations. For both these DNA markers, the South African populations were distinct from Eurasian populations, but always stemmed from a European origin. The data suggest that South African and European M. spicatum share a common ancestor, however the divergence of both markers are characteristic of a long period of isolation rather than a recent introduction from Europe. The genetic data from this study suggest that $M$. spicatum has not been introduced recently, but is most likely a native component of the South African flora.
\end{abstract}

\section{Introduction}

The geographic origin of exotic species is an important aspect of invasion biology (Goolsby et al., 2006; Le Roux and Wieczorek, 2009). Invasive species carry a genetic footprint into their introduced range that can often be traced back to the native geographic range (Petit et al., 2003; Taylor and Keller, 2007; Thum et al., 2011; Paterson et al., 2009; Paterson and Zachariades, 2013). Phylogeographic approaches using molecular markers are effective in determining invasion history (Schaal et al., 2003) and have been applied to several introduced plant species to determine their geographic origins and understand their introduction history (e.g. Madeira et al., 1997; Novak and Mack, 2001; Gaskin et al., 2005; Goolsby et al., 2006; Taylor and Keller, 2007; Paterson et al., 2009; Gaskin et al., 2011; Thum et al., 2011; Paterson and Zachariades, 2013).

There is debate over the native status of Myriophyllum spicatum L. (Haloragaceae) in South Africa. Van der Meijden and Caspers (1971) consider M. spicatum a native component of the aquatic flora in the highlands of East Africa, and according to their distribution map, the whole of southern and East Africa is part of the native distribution. The natural distribution of M. spicatum described by Cook (1985) did not include South Africa. However, Cook (2004) later treated M. spicatum as native to South Africa, Namibia and Botswana because there was no evidence to suggest it was introduced and was not considered problematic (Cook personal communication). In addition to this, several ecological studies in South Africa have not made any reference to M. spicatum being introduced or problematic, and often refer to it as an important component of the aquatic flora of the region (Boltt, 1969; Boltt et al., 1969; Breen and Jones, 1971; Allanson et al., 1974; Jacot Guillarmod, 1976; Howard-Williams, 1979; Jacot Guillarmod, 1979).

Conversely, Mendes (1978) reports in Flora Zambesiaca that the genus Myriophyllum is represented by two exotic species south of the Sahara, namely Myriophyllum aquaticum (Vell.) Verdc. and M. spicatum. In South Africa, M. spicatum is listed under the National Environment Management: Biodiversity Act (NEMBA), 2004 and Conservation of Agricultural Resources Act (CARA), 1983 as a Cat-egory 1 weed, which is the highest category an exotic weed can attain. This status was applied as a precautionary measure due to the plant's weedy behavior in other parts of the world, especially the U.S.A. (Henderson personal communication). Despite being recorded in the country since 1829 (Weyl and Coetzee, 2014), it has only been reported as being problematic as recently as 2005 (Coetzee et al., 2011). 
The debate over whether $M$. spicatum is native or introduced to South Africa has important implications for developing and implementing a control programme (Coetzee et al., 2011), especially whether or not biological control would be feasible. There are very few cases where biological control has been used on a native weed. Therefore, the aim of this study was to investigate the genetic relationships between populations of $M$. spicatum in South Africa versus those in the native Eurasian range to determine whether there is evidence for recent introduction(s) into South Africa. If $M$. spicatum was recently introduced from Eurasia, we would expect that South African populations will share haplotypes with Eurasian populations or have haplotypes that are nested within Eurasian haplotypes networks. In contrast, the identification of haplotypes that are unique to South Africa would provide evidence that the species was not recently introduced.

\section{Materials and methods}

A total of 40 populations of $M$. spicatum were sampled from throughout the native Eurasian range and South Africa (Table 1). At least 10 apical sections $\sim 5-10 \mathrm{~cm}$ long were collected from each population, loosely wrapped in paper towels, and placed in a Ziplock bag with silica gel. All plants were cleaned before drying to minimize sources of DNA contamination from other organisms (e.g. periphyton). GPS records and in most cases, a photograph of the plants was taken for identification purposes. DNA was extracted from dried leaf material or apical meristems using the DNeasy Plant Mini Kits (Qiagen) following the manufacturers' protocol.

The internal transcribed spacer regions (ITS) of the nuclear ribosomal DNA and a chloroplast DNA (cpDNA) intron trnQ-rps 16 were used in this study. The ITS region has previously been shown to provide intraspecific variability among Myriophyllum (Moody and Les, 2010; Thum et al., 2011); and has been used to identify multiple genotypes in introduced $M$. spicatum populations (Zuellig and Thum, 2012). The cpDNA intron trnQ-rps 16 was chosen from a suite of introns for its high intraspecific variability in M. spicatum.

The nuclear ribosomal DNA Internal Transcribed Spacers 1 and 2 and the intervening $5.8 \mathrm{~S}$ ribosomal subunit (hereafter ITS) was amplified using the universal primers ITS1 and ITS4 (Soltis and Kuzoff, 1995). The PCR reactions for the ITS region followed the standard protocol outlined in Thum et al. (2011) and contained the following: $1 \mu \mathrm{l}$ of PCR buffer (Invitrogen), $2 \mathrm{mM} \mathrm{MgCl}, 0.2 \mathrm{M}$ each primer, 0.2 M each dNTP, 1 unit of Taq DNA polymerase (Invitrogen), $1 \mu \mathrm{l}$ template DNA and brought to a total volume of $10 \mu \mathrm{l}$ with sterile, distilled and deionized water. Thermal cycling protocol was as follows: one cycle at $94^{\circ} \mathrm{C}$ for 2 min followed by 25 cycles of $94^{\circ} \mathrm{C}$ for $1 \mathrm{~min}, 53^{\circ} \mathrm{C}$ for $30 \mathrm{~s}, 72^{\circ} \mathrm{C}$ for $1 \mathrm{~min}$ and a final extension at $72^{\circ} \mathrm{C}$ for $8 \mathrm{~min}$. 1X PCR buffer

The chloroplast DNA trnQ-rps 16 intron region (hereafter cpDNA) was amplified using the primers $\operatorname{trn} \mathrm{Q}^{(\mathrm{UUG})}$ and $\operatorname{rps} 16 \times 1$ (Shaw et al., 2007) followed the protocol of Shaw et al. (2007). The PCR reactions for the CPDNA region contained the following: $1 \mu \mathrm{l}$ of PCR buffer (Invitrogen), $2 \mathrm{mM} \mathrm{MgCl}_{2}, 2 \mu \mathrm{mol}$ each primer, $0.2 \mathrm{mM}$ each dNTP, 1 unit of Taq DNA polymerase (Invitrogen), $1 \mu \mathrm{l}$ template DNA and brought to a total volume of $10 \mu \mathrm{l}$ with sterile, distilled and deionized water. The thermal cycling protocol was as follows: one cycle at $80^{\circ} \mathrm{C}$ for $5 \mathrm{~min}$ followed by 30 cycles of $95^{\circ} \mathrm{C}$ for $1 \mathrm{~min}, 50^{\circ} \mathrm{C}$ for $1 \mathrm{~min}$ (followed by a ramp of $0.3^{\circ} \mathrm{C} / \mathrm{s}$ to $65^{\circ} \mathrm{C}$ ), $65^{\circ} \mathrm{C}$ for $4 \mathrm{~min}$ and a final extension step of $5 \mathrm{~min}$ at $65^{\circ} \mathrm{C}$.

All PCR products were visualized on $1.5 \%$ agarose gel in TAE buffer stained with Ethidium Bromide or SYBR Safe (Life Technologies) to check for size and purity. The remaining DNA was treated with the enzymes Exonuclease I (New England Biolabs) and Antarctic Phosphatase (New England Biolabs) or ExoSAP-IT (Affymetrix) to eliminate unincorporated primers and dNTPs before sequencing.
The PCR products were sequenced using the same primers used for PCR and BigDye terminator chemistry (Applied Biosystems) on ABI $3130 x \mathrm{x}$ and $3730 \times 1$ DNA sequencers. In cases where the ITS PCR products did not produce clean and unambiguous sequences, the PCR products were cloned using the TOPO TA cloning kit (Invitrogen) and 5-10 positive inserts were sequenced.

Chromatograms were assembled and edited in Sequencher 4.2 (GeneCodes Corp). ITS sequence alignments were proofread manually and aligned using ClustalW as implemented in Mega 3.1 (Kumar et al., 2004) with default parameters. The cpDNA was manually aligned using MacClade 4.08 (Maddison and Maddison, 2005) and indels were determined following Moody and Les (2010) and expressed as binary characters (T/A) at the end of the sequence. Where singletons were present in the ITS dataset for cloned individuals (one base change in a single sequence), these were replaced with a "?" to take a conservative approach and reduce the possibility of cloning error. When the ITS sequence was identical for different individuals from the same location, only one sequence was used for further analysis. There were a total of 18 indels identified in the cpDNA region for the $M$. spicatum samples that were used.

Haplotype networks were constructed for both ITS and cpDNA using statistical parsimony (Templeton et al., 1992), as implemented in the program TCS version 1.21 (Clement et al., 2000), with a $95 \%$ connection limit, with gaps treated as missing data. This methodology is especially useful for estimating genealogical relationships at the population level where ancestral haplotypes are present and traditional phylogenetic methods require larger numbers of variable characters than are not usually available at the population level. Haplotype networks have been successfully used in several studies to identify relationships at the population level with submerged macrophytes (Thum et al., 2011; Zuellig and Thum, 2012).

\section{Results}

The final ITS alignment was $671 \mathrm{bp}$. Eight unique ITS haplotypes were identified among the samples of $M$. spicatum, which was represented as a network (Fig. 1). One loop was identified in the ITS haplotype network between the $\mathrm{H}_{6}, \mathrm{H}_{7}$ and $\mathrm{H}_{8}$ haplotypes, all of which occur in South Africa.

The ITS haplotypes found in South African populations $\left(\mathrm{H}_{6}, \mathrm{H}_{7}\right.$ and $\mathrm{H}_{8}$ ) were not found in any Eurasian populations, but geographically disparate South African populations shared haplotypes (Fig. 1; Table 2). For example, Lake Sibaya, Western Cape and Vaal River shared the ITS haplotype $\mathrm{H}_{7}$, and the Hogsback and the Vaal River populations shared ITS haplotype $\mathrm{H}_{6}$ (Fig. 1).

Several western European populations of M. spicatum (Belgium, France, Germany, Denmark, Scotland and Sweden) shared the same haplotype, $\mathrm{H}_{1}$ (Fig. 1). There was little diversity at the ITS region for populations in Europe or Asia. The France population, FR03, shared the $\mathrm{H}_{5}$ haplotype with the Scotland population, SC01, with both of these populations being one mutational step away from the $\mathrm{H}_{1}$ haplotype (Fig. 1; Table 2). The populations collected in Asia were between two and three mutational steps from $\mathrm{H}_{1}$ haplotype, separated by the $\mathrm{H}_{2}$ haplotype, which is European dominated, between the Asian $\mathrm{H}_{3}$ and $\mathrm{H}_{4}$ haplotypes and the ancestral haplotype, $\mathrm{H}_{1}$.

The final alignment of the cpDNA was $727 \mathrm{bp}$ including the 18 indels. There were 14 unique haplotypes represented in the network (Fig. 2; Table 2). One loop was identified in the haplotype network involving the European and Asian lineages (Fig. 2). It was not possible obtain cpDNA for all populations represented in the ITS alignment, however sequences from each of the major ITS haplotypes in South Africa, $\mathrm{H}_{6}$ and $\mathrm{H}_{7}$, Lake Sibaya/Western Cape/Vaal River and Vaal River/Hogsback, were obtained. 
Table 1

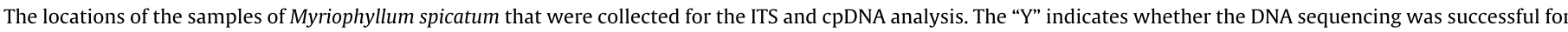
each of the markers, ITS and cPDNA.

\begin{tabular}{|c|c|c|c|c|c|}
\hline Code & Location & Latitude & Longitude & ITS & cpDNA \\
\hline AF003 & Vaalharts Weir, Vaal River, South Africa & -28.0916 & 24.9682 & Y & \\
\hline AF004 & Barkley West, Vaal River, South Africa & -28.5503 & 24.5317 & $\mathrm{Y}$ & \\
\hline AF005 & Lake Sibaya, Zululand, South Africa & -27.36 & 32.7132 & $\mathrm{Y}$ & $\mathrm{Y}$ \\
\hline AF007 & D. Impson pond ex. Nuwejaars River, South Africa & -34.676 & 19.914 & $\mathrm{Y}$ & $\mathrm{Y}$ \\
\hline AF008 & Vaalharts Weir, Vaal River, South Africa & -28.09164 & 24.96824 & $\mathrm{Y}$ & $\mathrm{Y}$ \\
\hline AF009 & Klipplaat River, Hogsback, South Africa & -32.49387 & 26.94959 & $\mathrm{Y}$ & $\mathrm{Y}$ \\
\hline AF011 & Prieska, Orange River, South Africa & -29.65969 & 22.74911 & & $\mathrm{Y}$ \\
\hline Belg001 & Dessel/SchötenChannel, Retie, Belgium & 51.27733 & 5.15074 & $\mathrm{Y}$ & \\
\hline Belg002 & Dessel/SchötenChannel, Turnhout, Belgium & 51.32692 & 4.92699 & $\mathrm{Y}$ & \\
\hline Belg004 & Dessel/SchötenChannel, Sint-Job-in-t'-Goor, Belgium & 51.29949 & 4.56313 & $\mathrm{Y}$ & \\
\hline DEN001 & Gudenå, Denmark & 56.383561 & 9.727819 & $\mathrm{Y}$ & $\mathrm{Y}$ \\
\hline DEN004 & Stilling Lk, Denmark & 56.06448 & 10.02274 & $\mathrm{Y}$ & \\
\hline DEN005 & Knudsø, Denmark & 56.104162 & 9.783341 & $\mathrm{Y}$ & \\
\hline DEN007 & Margrethe Kos, Denmark & 54.937196 & 8.703486 & & $\mathrm{Y}$ \\
\hline FR001 & Yvonand, France & 46.802845 & 6.732063 & $\mathrm{Y}$ & $\mathrm{Y}$ \\
\hline FR002 & Camargue, France & 43.68 & 4.63 & $\mathrm{Y}$ & $\mathrm{Y}$ \\
\hline FR003 & Lac du Couze, France & 45.098948 & 1.462235 & $\mathrm{Y}$ & $\mathrm{Y}$ \\
\hline FR004 & Bandeville, France & 48.57626 & 2.026683 & $\mathrm{Y}$ & $\mathrm{Y}$ \\
\hline FR005 & Herepian, France & 43.589261 & 3.102808 & $\mathrm{Y}$ & \\
\hline FR007 & Lacoste, France & 43.560184 & 3.302629 & Y & \\
\hline FR008 & Gignac, France & 43.652202 & 3.53083 & $\mathrm{Y}$ & \\
\hline GRM001 & Were River, Lohne, Germany & 52.18489 & 8.66707 & $\mathrm{Y}$ & \\
\hline GRM004 & River Oker, Braunschweig-WatenbYttel in Lower Saxony, Germany & 52.31056 & 10.46528 & $\mathrm{Y}$ & $\mathrm{Y}$ \\
\hline SCO001 & Loch Leven, Scotland & 56.206069 & -3.37728 & $\mathrm{Y}$ & $\mathrm{Y}$ \\
\hline SWE001 & Hudiksvall, Sweden & 61.720232 & 17.13665 & $\mathrm{Y}$ & $\mathrm{Y}$ \\
\hline SWL001 & River Treene, Ipland (near Treia) in Schleswig-Holstein & 54.53034 & 9.28958 & $\mathrm{Y}$ & \\
\hline IND001 & Kasmir University & 34.133122 & 74.84200 & $\mathrm{Y}$ & \\
\hline $\mathrm{CH} 1825$ & Behai, TengChong, Yunnan province, China & 25.1205 & 98.5586 & Y & $\mathrm{Y}$ \\
\hline $\mathrm{CH} 1775$ & Laogao yu tang, Mjan ning, Sichuan province, China & 28.538727 & 102.1569 & $\mathrm{Y}$ & \\
\hline CH3592 & Daga Town, Qushui county, Tibet & 29.336746 & 90.68417 & $\mathrm{Y}$ & $\mathrm{Y}$ \\
\hline CHNOO2 & Wuhan Botanical Gardens, Wuhan City, Hubei Province, China & 30.545264 & 114.4180 & & $\mathrm{Y}$ \\
\hline CHN003 & Kunming Lake of Summer Palace, Beijing, China & 39.993662 & 116.2610 & & $\mathrm{Y}$ \\
\hline CHN004 & Nahu Park, Changchun City, Jilin Province, China & 43.851125 & 125.2991 & & $\mathrm{Y}$ \\
\hline CHNO05 & YanQi Lake, Yanquing District, Bejing City, China & 40.396699 & 116.6768 & & $\mathrm{Y}$ \\
\hline WU 40 & Bosten Lake, Xinjiang, China & 41.9067 & 86.7314 & $\mathrm{Y}$ & \\
\hline WU 49 & Bosten Lake, Xinjiang, China & 41.9067 & 86.7314 & & $\mathrm{Y}$ \\
\hline WU 120 & Fuyang, Zhejiang, China & 29.9944 & 119.6944 & $\mathrm{Y}$ & $\mathrm{Y}$ \\
\hline WU 127 & Tai Lake, Jiangsu, China & 31.2228 & 120.4461 & & $\mathrm{Y}$ \\
\hline WU 128 & Tai Lake, Jiangsu, China & 31.2228 & 120.4461 & & $\mathrm{Y}$ \\
\hline KOR001 & Shihwa Lake, Seonah Jeong, Jihee Kim, South Korea & 37.2792 & 126.6242 & & $\mathrm{Y}$ \\
\hline
\end{tabular}

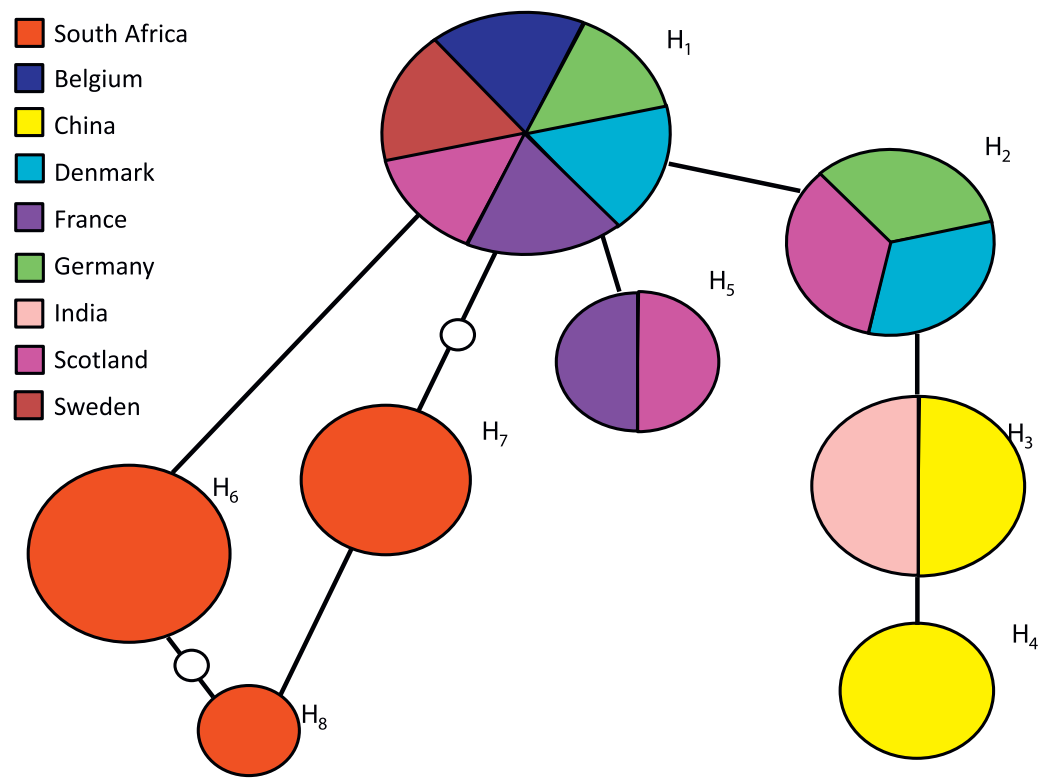

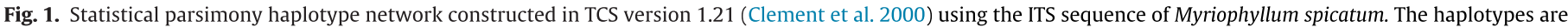

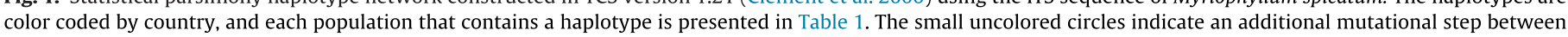
haplotypes detected. The circle sizes are proportional to the number of populations from where that haplotype was found. 


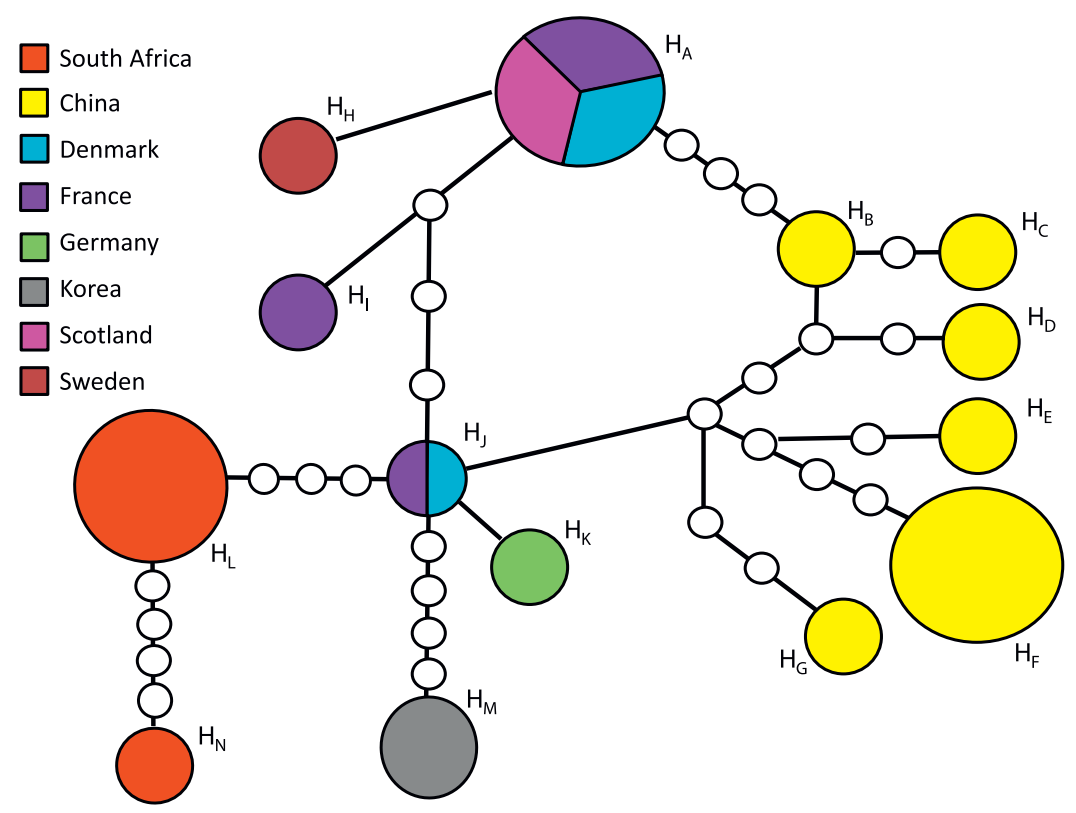

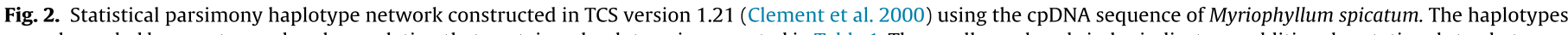

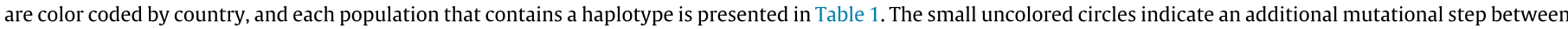
haplotypes detected. The circle sizes are proportional to the number of populations from where that haplotype was found.

The South African populations consisted of two haplotypes, $\mathrm{H}_{\mathrm{L}}$ and $\mathrm{H}_{\mathrm{N}}$, which is expected given their geographic isolation from each other. None of the South African haplotypes were found in any of the Eurasian populations, and are distinct from Eurasian haplotypes by a minimum of 4 mutational steps (Fig. 2).

The largest haplotype from the cpDNA network, $\mathrm{H}_{\mathrm{A}}$, included populations from France, Denmark and Scotland (Fig. 2; Table 2). There is a loop connecting the this haplotype and another haplotype found in populations from France and Denmark $\left(\mathrm{H}_{\mathrm{J}}\right)$ to a group containing samples from a wide geographic area of China $\left(\mathrm{H}_{B}\right.$, $\mathrm{H}_{\mathrm{C}}, \mathrm{H}_{\mathrm{D}}, \mathrm{H}_{\mathrm{E}}, \mathrm{H}_{\mathrm{F}}$ and $\mathrm{H}_{\mathrm{G}}$ ). These Chinese haplotypes are at least four mutational steps removed from all European haplotypes (Fig. 2; Table 2). The South Korean haplotype, $\mathrm{H}_{\mathrm{M}}$, stems from the European haplotype $\mathrm{H}_{\mathrm{J}}$ differing by five mutational steps. The South African haplotypes also stem from haplotype $\mathrm{H}_{\mathrm{J}}$ differing by 4 mutational steps. There was a relatively large amount of variability in the cpDNA region for all the biogeographical regions including the Asian, European and South African populations sampled (Fig. 2).

\section{Discussion}

The results from both the ITS and cpDNA analyses demonstrate that the South African populations of M. spicatum sampled in this study are unique not appearing in populations sampled throughout the European and Asian range. The South African populations do not share any ITS or cpDNA haplotypes with either the European or Asian populations sampled in our study. If the South African $M$. spicatum were introduced from Eurasia, it would be expected that populations would share ITS and/or cpDNA haplotypes with samples from the Eurasian range, or for South African haplotypes to be nested within the European and Asian accessions through the network analyses. Thus, the genetic data do not support the hypothesis that $M$. spicatum was recently introduced from Eurasia.

The data from this study were unable to identify a region or population of origin in Eurasia for M. spicatum in South Africa, however, the divergence stemming from the European lineage for both ITS and cpDNA suggests that the European and South African plants share a common ancestor. The important questions raised from this analysis, and which have important implications for determining the status (native versus introduced) of $M$. spicatum in South Africa, are the time of divergence between the South African and European lineages, and the mechanism(s) of dispersal into South Africa (natural versus anthropogenic).

Many aquatic plant introductions have been linked to the aquarium plant trade (Madeira et al., 2007; Martin and Coetzee, 2011). The first record of $M$. spicatum in South Africa, in 1829, predates the aquarium trade (Weyl and Coetzee, 2014), but South Africa does have a long history of cultural and economic exchange with Europe (Les and Mehrhoff, 1999), and it is plausible that M. spicatum could have been introduced from Europe around that time. Given the genetic distances between South African and European haplotypes in our study however, it is unlikely that the common ancestor of South African and European M. spicatum coincides with the first record in South Africa. The divergent South African ITS and cpDNA alleles are more consistent with long-term geographic isolation rather than a recent introduction. Alternatively, it is possible that the South African samples originate from European ancestors that were either not sampled or have gone extinct. However, we find this unlikely because the divergence between South African and European haplotypes was greater than the divergence among European haplotypes. Analyses of additional molecular markers and additional geographic sampling, especially geographic regions that may be dispersal routes including North Africa and the Arabic Peninsula, could be used to further test this hypothesis.

It is common for aquatic plants to have wide geographical ranges, and in many cases to have intercontinental disjunct distributions (Santamaría, 2002; Les et al., 2003), which makes natural dispersal of $M$. spicatum to South Africa plausible. Many species found in both Eurasia and South Africa have long evolutionary histories, with divergence times dating back to between the Cretaceous and the Eocene, with many of these distributions linked to continental drift (Les et al., 2003; Mao et al., 2012; Baker and Couvreur, 2013). However, the divergence of $M$. spicatum and its sister species, Myriophyllum sibiricum Kom. was in the Quaternary approximately 5 million years ago (Chen et al., 2014) which is considered recent in geological time. This distribution across continents is relatively common in aquatic taxa, where many species with recent divergence times, 2.5 million years or less, have 
Table 2

The haplotype allocations for both ITS and cpDNA for each Myriophyllum spicatum population identified by the statistical parsimony haplotype network. * Refers to the GenBank Accession numbers for the sequence relating to each haplotype.

\begin{tabular}{|c|c|c|}
\hline Code & ITS & cpDNA \\
\hline AF003 & $\mathbf{H}_{6}$ & - \\
\hline AF004 & $\mathbf{H}_{6}$ & - \\
\hline AF005 & $\mathbf{H}_{7}$ & $\mathbf{H}_{L}$ \\
\hline AF007 & $\mathbf{H}_{7}$ & $\mathbf{H}_{L}$ \\
\hline AF008 & $\mathbf{H}_{6}, \mathbf{H}_{7}$ & $\mathbf{H}_{L}$ \\
\hline AF009 & $\mathbf{H}_{6}, \mathbf{H}_{8}$ & $\mathbf{H}_{N}$ \\
\hline AF011 & - & $\mathbf{H}_{L}$ \\
\hline BELG001 & $\mathbf{H}_{1}$ & - \\
\hline BELG002 & $\mathbf{H}_{1}$ & - \\
\hline DEN001 & $\mathbf{H}_{1}$ & $\mathbf{H}_{A}$ \\
\hline DEN004 & $\mathbf{H}_{1}$ & $\mathbf{H}_{A}$ \\
\hline DEN005 & $\mathbf{H}_{2}$ & $\mathbf{H}_{J}$ \\
\hline DEN007 & & $\mathbf{H}_{J}$ \\
\hline FR001 & $\mathbf{H}_{1}$ & $\mathbf{H}_{J}$ \\
\hline FR002 & $\mathbf{H}_{1}$ & $\mathbf{H}_{A}$ \\
\hline FR003 & $\mathbf{H}_{5}$ & $\mathbf{H}_{I}$ \\
\hline FR004 & $\mathbf{H}_{1}$ & $\mathbf{H}_{J}$ \\
\hline FR005 & $\mathbf{H}_{1}$ & - \\
\hline FR007 & $\mathbf{H}_{1}$ & - \\
\hline FR008 & $\mathbf{H}_{1}$ & - \\
\hline GRM001 & $\mathbf{H}_{1}, \mathbf{H}_{2}$ & - \\
\hline GRM004 & $\mathbf{H}_{1}$ & $\mathbf{H}_{K}$ \\
\hline SCO001 & $\mathbf{H}_{1}, \mathbf{H}_{2}$ & $\mathbf{H}_{A}$ \\
\hline SWE001 & $\mathbf{H}_{1}, \mathbf{H}_{2}$ & $\mathbf{H}_{H}$ \\
\hline SWL001 & $\mathbf{H}_{2}$ & - \\
\hline IND001 & $\mathbf{H}_{3}$ & - \\
\hline $\mathrm{CH} 1825$ & $\mathbf{H}_{3}$ & $\mathbf{H}_{D}$ \\
\hline $\mathrm{CH} 1775$ & $\mathbf{H}_{3}$ & - \\
\hline CH3592 & $\mathbf{H}_{3}$ & $\mathbf{H}_{G}$ \\
\hline CHNOO2 & - & $\mathbf{H}_{F}$ \\
\hline CHNO03 & - & $\mathbf{H}_{C}$ \\
\hline CHNOO4 & - & $\mathbf{H}_{B}$ \\
\hline WU 40 & $\mathbf{H}_{4}$ & - \\
\hline WU49 & - & $\mathbf{H}_{E}$ \\
\hline WU 120 & $\mathbf{H}_{4}$ & $\mathbf{H}_{F}$ \\
\hline WU127 & - & $\mathbf{H}_{F}$ \\
\hline WU128 & - & $\mathbf{H}_{F}$ \\
\hline KOR001 & - & $\mathbf{H}_{M}$ \\
\hline
\end{tabular}

${ }^{*}$ GenBank accession numbers for each haplotype: $\mathrm{H}_{1}$ : KT783507; $\mathrm{H}_{2}$ : KT783508; $\mathrm{H}_{3}$ : KT783509; $\mathrm{H}_{4}:$ KT783510; $\mathrm{H}_{5}:$ KT783511; $\mathrm{H}_{6}: \mathrm{KT} 783512 ; \mathrm{H}_{7}: \mathrm{KT} 783513 ;$ $\mathrm{H}_{8}: \mathrm{KT} 783514 ; \mathrm{H}_{\mathrm{A}}: \mathrm{KT} 783493 ; \mathrm{H}_{\mathrm{B}}: \mathrm{KT} 783494 ; \mathrm{H}_{\mathrm{C}}: \mathrm{KT} 783495 ; \mathrm{H}_{\mathrm{D}}: \mathrm{KT} 783496$

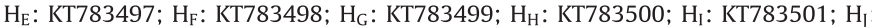
KT783502; $\mathrm{H}_{\mathrm{K}}:$ KT783503; $\mathrm{H}_{\mathrm{L}}: \mathrm{KT} 783504 ; \mathrm{H}_{\mathrm{M}}$ : KT783505; $\mathrm{H}_{\mathrm{N}}:$ KT783506

disjunct distributions between continents or major geographical barriers (Les et al., 2003). There has been a lot controversy over the mechanisms of long distance dispersal between the continents (Sculthorpe 1967; Clausen et al., 2002), however, natural dispersal from Europe to South Africa via historical water bodies connecting north of the Sahara to the rest of Africa (Drake et al., 2011) could be possible through bird dispersal (Clausen et al., 2002) in the last 5 million years.

The data presented thus far do not provide evidence for the recent anthropogenic introduction of $M$. spicatum from the Eurasian range, despite the extensive sampling across this region. The data are more consistent with geographically isolated populations that shared a common ancestor that predates the opportunities for anthropogenic introductions. It is, of course, possible that additional sampling and genetic analysis would provide evidence for a recent introduction of $M$. spicatum, but our data provide no evidence of such. Therefore, we conclude that $M$. spicatum is more likely a native component of the South African flora than a recent introduction from Eurasia.

\section{Acknowledgments}

Many thanks to the local and international colleagues who assisted this study by collecting genetic material from all over the globe: Antoine Gander, Carla Lambertini, Dean Impson, Iain Gunn, Kristina Steffen, Lesley Henderson, Patrick Grillas, Rene Sforza, Roger Monge, Rosemary Mangan, Sangkyu Park, Seonah Jeong, Shahzada Arshid, Steve Compton, Tenna Riis, Xinwei Xu. Without them, this study would not have been possible. Assistance with collection of molecular data was provided by Christopher Anderson, Meghan Jeffers, Nayell Palomino, Jeffrey Pashnick, Andrew Pyman, and Dustin Wcisel. The Working for Water Programme of the Natural Resource Management Programmes (Department of Environmental Affairs), South Africa and University of Minnesota CFANS faculty development award are thanked for their financial support of this project.

\section{References}

Allanson, B.R., Bruton, M.N., Hart, R.C., 1974. The plants and animals of Lake Sibaya KwaZulu, South Africa: a checklist. Rev. de Zool. Afr. 88, 507-532.

Baker, W.J., Couvreur, T.L., 2013. Global biogeography and diversification of palms sheds light on the evolution of tropical lineages. I. Historical biogeography. J. Biogeogr. 40, 274-285.

Boltt, R.E., 1969. The benthos of some southern African lakes: Part II. The epifauna and infauna of the benthos of Lake Sibayi. Trans. R. Soc. South Afr. 38, 249-270.

Boltt, R.E., Hill, B.J., Forbes, A.T., 1969. The benthos of some southern African lakes: Part I: distribution of aquatic macrophytes and fish in Lake Sibayi. Trans. R. Soc. South Afr. 38, 241-248.

Breen, C.M., Jones, I.D., 1971. A preliminary list of Angiosperms collected in the vicinity of Lake Sibayi. Trans. R. Soc. South Afr. 39, 235-245.

Chen, L.Y., Zhao, S.Y., Mao, K.S., Les, D.H., Wang, Q.F., Moody, M.L., 2014. Historica biogeography of Haloragaceae: an out-of-Australia hypothesis with multiple intercontinental dispersals. Mol. Phylogenet. Evol. 78, 87-95.

Clausen, P., Nolet, B.A., Fox, A.D., Klaassen, M., 2002. Long-distance endozoochorous dispersal of submerged macrophyte seeds by migratory waterbirds in northern Europe-a critical review of possibilities and limitations. Acta Oecol. 23, 191-203.

Clement, M., Posada, D., Crandall, K.A., 2000. TCS: a computer program to estimate gene genealogies. Mol. Ecol. 9, 1657-1659.

Coetzee, J.A., Bownes, A., Martin, G.D., 2011. Prospects for the biological control of submerged macrophytes in South Africa. Afr. Entomol. 19, 469-487.

Cook, C.D.K., 1985. Worldwide distribution and taxonomy of Myriophyllum species. In: Anderson, L.W.J. (Ed.), First International Symposium on Watermilfoil and Related Haloragaceae Species. Vancouver, pp. 1-7.

Cook, C.D.K., 2004. Aquatic and Wetland Plants of Southern Africa. Backhuys Publishers, Leiden

Drake, N.A., Blench, R.M., Armitage, S.J., Bristow, C.S., White, K.H., 2011. Ancient watercourses and biogeography of the Sahara explain the peopling of the desert. Proc. Natl. Acad. Sci. 108, 458-462.

Gaskin, J.F., Zhang, D.Y., Bon, M.C., 2005. Invasion of Lepidium draba (Brassicaceae) in the western United States: distributions and origins of chloroplast DNA haplotypes. Mol. Ecol. 14, 2331-2341.

Gaskin, J.F., Bon, M., Cock, M.J.W., Cristofaro, M., De Biase, A., De Clerck-Floate, R., Ellison, C.A., Hinz, H.L., Hufbauer, R.A., Julien, M.H., Sforza, R., 2011. Applying molecular-based approaches to classical biological control of weeds. Biol. Control 58, 1-21.

Goolsby, J.A., DeBarro, P.J., Makinson, J.R., Pemberton, R.W., Hartley, D.M., Frohlich, D.R., 2006. Matching the origin of an invasive weed for selection of a herbivore haplotype for a biological control programme. Mol. Ecol. 15, 287-297.

Howard?Williams, C., 1979. Distribution, biomass and role of aquatic macrophytes in Lake Sibaya. In: Allanson, B.R. (Ed.), Lake Sibaya. Dr. W. Junk Publishers, Boston, pp. 88-107.

Jacot Guillarmod, A., 1976. Myriophyllum, an increasing water weed menace for South Africa. In: Proceedings of the South African Association for Advanced Science, Nelspruit, pp. 93-100

Jacot Guillarmod, A., 1979. Water weeds in southern Africa. Aquat. Bot. 6, 377-391.

Kumar, S., Tamura, K., Nei, M., 2004. MEGA3: integrated software for molecular evolutionary genetics analysis and sequence alignment. Brief Bioinformatics 5 , 150-163.

Les, D.H., Mehrhoff, L.J., 1999. Introduction of non-indigenous aquatic vascular plants in southern New England: a historical perspective. Biol. Invasions 1, 281-300.

Les, D.H., Crawford, D.J., Kimball, R.T., Moody, M.L., Landoltk, E., 2003. Biogeography of discontinuously distributed hydrophytes: a molecular appraisal of intercontinental disjunctions. Int. J. Plant Sci. 164, 917-932

Le Roux, J.J., Wieczorek, A.M., 2009. Molecular systematics and population genetics of biological invasions: towards a better understanding of invasive species management. Ann. Appl. Biol. 154, 1-17

Maddison, D.R., Maddison, W.P., 2005. MacClade 4: Analysis of phylogeny and character evolution. Version 4.08a. http://macclade.org.

Madeira, P.T., Van, T.K., Steward, K.K., Schnell, R.J., 1997. Random amplified polymorphic DNA analysis of the phenetic relationships among world-wide accessions of Hydrilla verticillata. Aquat. Bot. 59, 217-236. 
Madeira, P.T., Coetzee, J.A., Center, T.D., White, E.E., Tipping, P.W., 2007. The origin of Hydrilla verticillata recently discovered at a South African dam. Aquat. Bot. 87, 176-180.

Mao, K., Milne, R.I., Zhang, L., Peng, Y., Liu, J., Thomas, P., Mill, R.R., Renner, S.S., 2012. Distribution of living Cupressaceae reflects the breakup of Pangea. Proc. Natl. Acad. Sci. 109, 7793-7798.

Martin, G.D., Coetzee, J.A., 2011. Fresh water aquatic plant invasion risks posed by the aquarium trade: aquarists and the internet trade in South Africa. WaterSA 37, 371-380

Mendes, E.J., 1978. Haloragaceae. Flora Zambesiaca 4, 79-81.

Moody, M.L., Les, D.H., 2010. Systematics of the aquatic angiosperm genus Myriophyllum (Haloragaceae). Syst. Bot. 35, 1-19.

Novak, S.J., Mack, R.N., 2001. Tracing plant introduction and spread: genetic evidence from Bromus tectorum (Cheatgrass). Bioscience 51, 114-122.

Paterson, I.D., Zachariades, C., 2013. ISSRs indicate that Chromolaena odorata in southern Africa originates in Jamaica or Cuba. Biol. Control 66, 132 139.

Paterson, I.D., Hill, M.P., Downie, D.A., 2009. Using molecular methods to determine the origin of weed populations of Pereskia aculeata in South Africa and its relevance to biological control. Biol. Control 48, 84-91.

Petit, R.J., Aguinagalde, I., De Beaulieu, J.L., Bittkau, C., Brewer, S., Cheddadi, R. Ennos, R., Fineschi, S., Grivet, D., Lascoux, M., Mohanty, A., Muller-Starck, G. Demesure-Musch, B., Palmé, A., Martín, J.P., Rendell, S., Vendramin, G.G., 2003. Glacial refugia: hotspots but not melting pots of genetic diversity. Science 300 1563-1565.

Santamaría, L., 2002. Why are most aquatic plants broadly distributed? Dispersal, clonal growth and small-scale heterogeneity in a stressful environment. Acta Oecol. 23, 137-154.
Schaal, B.A., Gaskin, J.F., Caicedo, A.L., 2003. The Wilhelmine E. key 2002 invitational lecture. Phylogeography, haplotype trees, and invasive plant species. J. Hered. 94, 197-204.

Sculthorpe, C.D., 1967. The Biology of Aquatic Vascular Plants. Edward Arnold Ltd., London.

Shaw, J., Lickey, E.B., Schilling, E.E., Small, R.L., 2007. Comparison of whole chloroplast genome sequences to choose noncoding regions for phylogenetic studies in angiosperms: the tortoise and the hare III. Am. J. Bot. 94, 275-288.

Soltis, D.E., Kuzoff, R.K., 1995. Discordance between molecular and chloroplast phylogenies in the Heuchera group (Saxifragaceae). Evolution 49, 727-742.

Taylor, D.R., Keller, S.R., 2007. Historical range expansion determines the phylogenetic diversity introduced during contemporary species invasion. Evolution 61, 334-345.

Templeton, A.R., Crandall, K.A., Sing, C.F., 1992. A cladistic analysis of phenotypic associations with haplotypes inferred from restriction endonuclease mapping and DNA sequence data III. Cladogram estimation. Genetics 132, 619-633.

Thum, R.A., Zuellig, M.P., Moody, M.E., Johnson, R.L., Vossbrinck, C., 2011

Molecular markers reconstruct the invasion history of variable leaf watermilfoil (Myriophyllum heterophyllum) and distinguish it from closely related species. Biol. Invasions $13,1687-1709$.

Van der Meijden, R., Caspers, N., 1971. Haloragaceae. In: van Steenis, C.G.G.J. (Ed.), Flora Malesisiana, Vol.7. Wolters-Noordhoff Publishing, Groningen, pp. 239-263.

Weyl, P., Coetzee, J., 2014. The invasion status of Myriophyllum spicatum in southern Africa. Manag. Biol. Invasions 5, 31-37.

Zuellig, M.P., Thum, R.A., 2012. Multiple introductions of invasive Eurasian watermilfoil and recurrent hybridization with native northern watermilfoil in North America. J. Aquat. Plant Manag. 50, 1-19. 